\title{
Taming the Beast: \\ West Germany, the Political Offence Exception, and the Council of Europe Convention on the Suppression of Terrorism
}

The Strasbourg Convention represents the first collective undertaking by Western European governments to restrict severely the political offense exception to the offense of terrorism. ${ }^{1}$

Robert A. Friedlander

\section{INTRODUCTION ${ }^{\S}$}

On 27 January 1977, Western European ministers met in Strasbourg to solemnly sign a document that, the West German government hoped, would improve European extradition relations and would allegedly help their governments fight the growing menace of international terrorism: the European Convention on the Suppression of Terrorism. And indeed, the 1970s were troubled years for many Western governments. The social and student protests that had affected many of them in the 1960s had ebbed but some more radical members of the protests had gone underground and escalated the violence: the result was social-revolutionary terrorism. ${ }^{2}$ Yet at the same time, nationalist terrorist groups continued to exist or emerged in other parts of Europe. As a consequence, most European countries were at least indirectly - threatened by terrorism and the dangers deriving from it had become a serious concern for many governments. ${ }^{3}$ This essay will focus on West Germany's efforts as the country was particularly exposed to terrorism. While in the first few years the government tried to ignore the challenges terrorists posed, with the chancellorship of Helmut Schmidt this policy changed into a more proactive stance on anti-terrorism efforts and a more rigid refusal to negotiate with terrorists about political demands.

\footnotetext{
$\S$ This article was published in Terrorism and Political Violence, Vol. 27 No. 2, 2015, pp. 310-330.

${ }^{1}$ Robert A. Friedlander, "Terrorism and International Law: Recent Developments," Rutgers Law Journal 13, (1981-1982), 493-511: 500-501.

${ }^{2}$ Following David C. Rapoport's classification. See David C. Rapoport, "The Four Waves of Modern Terrorism," in Attacking Terrorism: Elements of A Grand Strategy, ed. Audrey Kurth Cronin and James M. Ludes(Washington: Georgetown University Press, 2004), 46-73. See also his more recent piece that takes into account more current developments: David C. Rapoport, "The Four Waves of Modern Terror: International Dimensions and Consequences," in An International History of Terrorism. Western and Non-Western Experiences, ed. Jussi M. Hanhimäki and Bernhard Blumenau(Oxon: Routledge, 2013), 282-310.

${ }^{3}$ Rapoport, "The Four Waves of Modern Terror: International Dimensions and Consequences," 290-295.
} 
This article looks at the German ${ }^{4}$ perspective on the negotiations amongst the members of the Council of Europe $(\mathrm{CoE})$ about a Convention on the Suppression of Terrorism in the mid-1970s. It assesses the complexity of the negotiations, the problems encountered, and the solutions designed as well as the difficulty of reaching a number of ratifications necessary for the Convention to enter into force. The political offence exception was the biggest bone of contention and the compromise - while not completely removing the exception - did oblige countries to try perpetrators of terrorist acts and therefore theoretically removed the possibility of terrorists escaping justice. From a historical perspective, the Convention is thus part of a broader trend towards multilateral cooperation. Despite its shortcomings, it demonstrates that countries were willing to limit existing legal loopholes, rather than creating more obstructions for the prosecution of political criminals. Aside from the - disputed - legal relevance of the Convention itself, the negotiation process as such provided all parties with a better understanding of the legal positions and regulations on terrorism and thus paved the way for more instruments to be negotiated in the following years, for instance at the European Communities level or bilaterally. For West Germany, the Convention was part of a bigger multilateral scheme against terrorism and its adoption had important symbolic meaning as a show of unity of European countries against terrorists.

The article draws upon recently declassified documents from the German Auswärtiges Amt (AA) as well as on secondary literature. It aims at contributing to closing the existing gap in scholarship not only on the history of terrorism, and West German international antiterrorism efforts but also as regards the role that international organisations played in the struggle against terrorism. The negotiations as the CoE provide a snapshot of the complexity of multilateral negotiations against terrorism in general and of the problems that even likeminded countries - such as Germany and France - face in cooperating on highly sensitive issues.

\section{The Council of Europe and Bonn's stance on the Political Offence Exception}

The Council of Europe was founded by ten countries on 5 May 1949 as an intergovernmental European organisation. Its primary objective was to promote cooperation among its members especially in economic, social, and cultural fields in order to overcome the scourge of war that had plagued the continent for centuries. Soon after its creation, the $\mathrm{CoE}$ began to place special emphasis on legal harmonisation between the member states. It

\footnotetext{
${ }^{4}$ In the context of this article, "German" or "Germany" refer to the Federal Republic of Germany.
} 
soon transpired that the promotion of the rule of law and increasing respect for human rights would be fundamental pillars of its work. In that sense, the CoE served as a cradle for the other institutions of European integration that were to become the European Communities (EC) and - eventually - the European Union. By 1989, the CoE had 23 Western European members. ${ }^{5}$ West Germany joined the CoE one year after its foundation, on 13 July 1950, as an associated member, and became a full member on 2 May 1951. Joining the organisation was a part of Konrad Adenauer's policy of Westintegration, which aimed at participating in international affairs and at regaining international trust for the shunned German state. In contrast to the FRG, the German Democratic Republic (GDR) never joined the CoE. ${ }^{6}$

Among the issues on the CoE's agenda was the question of extradition between member states. In 1957, it adopted a European Convention on Extradition to harmonise and facilitate the procedures for extradition. ${ }^{7}$ Yet when it came to offences related to terrorism, the convention was not up to the challenges of the 1970s as it still allowed an exemption from extradition - and in fact prosecution - for acts that were deemed political. ${ }^{8}$

This exemption was nothing new and the extradition of political criminals has always been a very sensitive issue. ${ }^{9}$ As a matter of fact it has been one of the most contested issues in international law for the past 150 years or so. ${ }^{10}$ Until the mid-20 $0^{\text {th }}$ century, extradition was predominantly the subject of bilateral treaties, which mostly featured an exception for perpetrators of what were considered political acts. Much like finding a definition for

\footnotetext{
${ }^{5}$ Bruno Haller, "Das paneuropäische Mandat des Europarats," in 50 Jahre Europarat, ed. Uwe Holtz(BadenBaden: Nomos, 2000), 51-70; Daniel Tarschys, "50 Jahre Europarat: der Weg nach einem Europa ohne Trennungslinien," in 50 Jahre Europarat, ed. Uwe Holtz(Baden-Baden: Nomos, 2000), 39-50: 39-41; Uwe Holtz, "50 Jahre Europarat - Eine Einführung," in 50 Jahre Europarat, ed. Uwe Holtz(Baden-Baden: Nomos, 2000), 11-36: 17-19; Johannes Dohmes, "Die Bedeutung des Europarats für Deutschland," in 50 Jahre Europarat, ed. Uwe Holtz(Baden-Baden: Nomos, 2000), 185-196.

${ }^{6}$ Dohmes, "Die Bedeutung des Europarats für Deutschland," 186-187; Thomas Schlinkmann, "Der Weg der Bundesrepublik Deutschland in den Europarat - Ein Exkurs," in 50 Jahre Europarat, ed. Uwe Holtz(BadenBaden: Nomos, 2000), 197-212.

${ }^{7}$ Paul O'Higgins, "European Convention on Extradition," The International and Comparative Law Quarterly 9 , no. 3 (1960), 491-494; Mark Mackarel and Susan Nash, "Extradition and the European Union," The International and Comparative Law Quarterly 46, no. 4 (1997), 948-957: 949-953.

${ }^{8}$ Art. 3 (1) of the European Convention on Extradition reads: "Extradition shall not be granted if the offence in respect of which it is requested is regarded by the requested Party as a political offence or as an offence connected with a political offence."

${ }^{9}$ For an extensive legal discussion of the political offence exceptions and its connections to extradition laws see for instance Geoff Gilbert, Responding to International Crime, International Studies in Human Rights (Leiden, Boston: Martinus Nijhoff Publishers, 2006), chapter 5.

${ }^{10}$ Already at the beginning of the $20^{\text {th }}$ century the political offence exception and its consequences were the subject of heavy academic discourse, see for instance J. Reuben Jr Clark, Frederic R. Coudert, and Julian W. Mack, "The Nature Definition of Political Offense in International Extradition," Proceedings of the American Society of International Law at Its Annual Meeting (1907-1917) 3, (1909), 95-165. For the historical context of these debates see for instance Richard Bach Jensen, "The First Global Wave of Terrorism and International Counter-terrorism, 1905-14," in An International History of Terrorism. Western and Non-Western Experiences, ed. Jussi M. Hanhimäki and Bernhard Blumenau(London: Routledge, 2013), 16-33.
} 
"terrorism" - to which it is normally intimately linked - the term "political offence" was usually kept vague, thus leaving great leeway to the country faced with a demand for extradition. ${ }^{11}$ The basic motivation for developing the concept of "political offence exceptions" was that, in theory, the state to which a fugitive fled could remain neutral about the internal affairs of a different state and not get involved by claiming that the suspect was a political offender. However, in practical terms, the very decision to invoke the exception and not to extradite (or try) a suspect could be interpreted as the asylum state taking a position on the domestic affairs of a different state. ${ }^{12}$ During the $19^{\text {th }}$ and first half of the $20^{\text {th }}$ century, the logic of maintaining a political offence exception was a consequence of the international system and the different regimes ruling various European countries. In the $19^{\text {th }}$ century, liberal England and France, for instance, were faced with conservative and reactionary regimes in Germany, Austria, and Russia. People accused of committing political or anarchist acts in one of the latter countries would seek refuge in England, for example, which might not want to deliver them to their home countries. Likewise, during the era of the conflict of ideologies, the Cold War, people accused of political offences in the Eastern Bloc would try to escape to, say, Western Europe and the governments there would not want to extradite them back to the Soviet Bloc. This even applied to the two Germanys. An East German who fled to West Germany would not be sent back to the GDR. The political implications and motives for maintaining a political offence exception were thus strongly rooted in the international system. The situation was different, however, when it came to more like-minded Western countries, where the exception could still also be applied. Consequently, by the early 1970s, extradition was difficult even between Western - and Western European - states because of the political offense clause. ${ }^{13}$ In the worst case, this exemption would mean that alleged perpetrators of an act of terrorism in one country would go unpunished because they had fled to another country where the suspect claimed that the alleged act was of a political nature and he or she would therefore fall under the political offence exemption. ${ }^{14}$ This was to be changed

\footnotetext{
${ }^{11}$ For an assessment of the situation in the early 1930 s, certainly a period when this was a very sensitive topic due to the authoritarian regimes that were installed in several European countries, see for instance Lora L. Deere, "Political Offenses in the Law and Practice of Extradition," The American Journal of International Law 27, no. 2 (1933), 247-270. She also provides a neat historical overview of the history of the political offence exception until the 1930s.

${ }^{12}$ Geoffrey S. Gilbert, "Terrorism and the Political Offence Exemption Reappraised," The International and Comparative Law Quarterly 34, no. 4 (1985), 695-723: 695-696.

${ }^{13}$ Abraham D. Sofaer, "Terrorism and the Law," Foreign Affairs 64, no. 5 (1986), 901-922: 907.

${ }^{14}$ See for example the case of the RAF lawyer Klaus Croissant who was accused of illegally helping the RAF and in 1977 fled to France claiming the status of a political refugee. Once the federal government asked for his extradition a wave of protest erupted in France, but despite the public pressure the government pursued the extradition request and the Cours d'Appel in Paris finally ruled that Croissant could be sent back to Germany.
} 
by the European Convention on the Suppression of Terrorism. The West Germans in particular were very active in trying to find an end to the political offence exemption in legal instruments. The idea was that even if a country decided not to extradite an offender because of political or racial or other reasons, the country still had to try him. ${ }^{15}$ As an internal memo of the Auswärtiges Amt (AA) elaborated: “A request for extradition shall no longer be denied because the underlying act for the request is considered a political crime, related to a political crime or a crime with a political motivation." 16 Another reason for Bonn to pursue its antiterrorism efforts at the $\mathrm{CoE}$ rather than elsewhere was the standstill that had emerged on terrorism issues in the mid-1970s at the UN:

As it was unclear when the efforts of the United Nations for a better coordination of the struggle against international terrorism would show results, the Council of Europe - within a limited regional area - contributed to the solution of the problems caused by certain typical terrorist crimes. ${ }^{17}$

A good synopsis of West German motivations for pursuing the project at the CoE was given in the memorandum attached to the convention when it was supposed to be adopted by the Bundestag:
All bilateral or multilateral conventions have in common that an extradition is not possible if the state from which extradition is requested considers the act responsible for the request as a political crime or as related to a political crime. [...] This often leads to a better position - de iure and de facto - of offenders claiming political motives compared with other criminals because prosecution in the country where the offender is held becomes difficult as the necessary evidence is hardly available nor do the judicial authorities want to prosecute. The priority of any agreement for improved international cooperation in fighting international terrorism should hence be to ascertain that people who have committed political crimes, crimes related to those, or politically motivated crimes in certain serious cases will also meet just punishment. Extradition serves this purpose best. Because the extradition to

\footnotetext{
During the whole process, it became clear that in broad circles of French society and bureaucracy there was certain sympathy for Croissant based on his claims of being a political refugee and hence exempt from extradition. See "Unmenschliches Deutschland?," Der Spiegel, no. 48 (1977), 132-139; "Paris: "Wir jagen Croissant"," Der Spiegel, no. 39 (1977), 127-129, 132; "Heiße Hölle," Der Spiegel, no. 46 (1977), 159-160; "Neuer Terrortyp," Der Spiegel, no. 44 (1977), 156-162.

${ }^{15}$ National Foreign Assessment Center: International Issues Review, 30.03.1979, NLC-23-44-2-4-2, CIA FOIA, Jimmy Carter Library (JCL).

${ }^{16}$ Memo: Denkschrift zu dem Übereinkommen, attached to Schnellbrief BMJ an das AA: Europäisches Übereinkommen vom 27. Januar 1977 zur Bekämpfung des Terrorismus, 09.09.1977, B83 1234, Politisches Archives des Auswärtiges Amtes (PA).

${ }^{17}$ Memo: Denkschrift zu dem Übereinkommen, attached to Schnellbrief BMJ an das AA: Europäisches Übereinkommen vom 27. Januar 1977 zur Bekämpfung des Terrorismus, 09.09.1977, B83 1234, PA. For an overview about West Germany's anti-terrorism efforts at the UN see Bernhard Blumenau, "The United Nations and West Germany's Efforts against International Terrorism in the 1970s," in An International History of Terrorism: Western and Non-Western Experiences, ed. Jussi Hanhimäki and Bernhard Blumenau(Oxon: Routledge, 2013), 66-85.
} 
the state where the crime was committed and where the evidence is available is normally the best way to hold an accused accountable in court. ${ }^{18}$

This text clearly highlights that for Germany, the best option to ensure prosecution was extradition. And if extradition could not be granted, the responsibility to try that person fell to the country on whose territory an offender was held. Further down in the document, the federal government once again highlighted the primary intention of the Convention but also acknowledged that it still had some shortcomings and did not go as far as Germany wished:

The basic intention of the Convention - to give priority to extradition of an offender - could not be entirely realised as member states had reserved the right to reject extradition requests under certain conditions in relation to the political character of the crime. However, because of the obligation of the rejecting state to try the offender itself the basic goal - to ensure prosecution is still realised.

The title of the instrument - the European Convention on the Suppression of Terrorism indicated, however, the willingness of Western European countries to fight the menace of terrorism. Certainly this had become a major issue for European countries.

\section{The Negotiations for the European Convention On the Suppression of TerRorism}

Given the general context of a growing menace of terrorism in the 1970s in Western Europe and the interest that Germany and other countries had in better regulating extradition situations, especially with a view to alleged terrorists, how did the European Convention come about?

When Count von Spreti, West Germany's ambassador to Guatemala, was assassinated by rebels in Guatemala in April 1970, Bonn realised that it had assumed a prominent position as a target of international terrorism. At the same time, domestic terrorism in the FRG was on the rise. Members of the German terrorist groups did not just act within the territory of West Germany but also crossed into neighbouring countries to plan attacks or escape punishment. West Germany's early encounters with international terrorism culminated in the Munich Hostage Crisis of $1972 .{ }^{19}$ But it was the proliferation of attacks against diplomats that motivated West Germany to turn to the CoE. In 1970, i.e. before the UN adopted the

\footnotetext{
${ }^{18}$ Deutscher Bundestag, Drucksache 8/1204: Denkschrift zum Übereinkommen, no date probably 1977 , Zwischenarchiv (ZA) 111264, PA, pp. 11-12. Emphasis added.

${ }^{19}$ See Eva Oberloskamp, "Das Olympia-Attentat 1972. Politische Lernprozesse im Umgang mit dem transnationalen Terrorismus," Vierteljahrshefte für Zeitgeschichte 60, no. 3 (2012), 321-352; Matthias Dahlke, Der Anschlag auf Olympia '72: Die politischen Reaktionen auf den internationalen Terrorismus in Deutschland (Munich: Martin Meidenbauer Verlag, 2006).
} 
Diplomats Convention, ${ }^{20}$ Bonn requested that the CoE discuss the prospects for a European convention for better protection of diplomats or an additional protocol to the Vienna Convention. ${ }^{21}$ This German initiative was referred to a committee of experts that was charged with investigating the political and legal issues involved. According to German plans, once the $\mathrm{CoE}$ had elaborated a convention, it could submit this as a proposal for the UN to follow. ${ }^{22}$ However, these plans coincided with the International Law Commission drafting the convention for better protection of diplomats and consequently this issue was not pursued by the $\mathrm{CoE}$ but rather delegated to the UN. As attacks against diplomats were a global problem and not only a danger for Western Europeans, the UN certainly seemed to be the more appropriate forum to design measures against this threat.

Nonetheless, the CoE remained concerned with the issue of terrorism. Triggered by the events in Munich, and against the backdrop of very cumbersome cross-border antiterrorism cooperation, the $\mathrm{CoE}$ dealt with the escalating problems related to the increase in international terrorism in Western Europe. On 26 October 1972, the CoE's Assembly approved Recommendation 684, which called for a survey on national measures taken by the member states to combat terrorism. It prompted member states to submit reports on national anti-terrorism legislation. ${ }^{23}$ The Resolution was strongly supported by Germany and France, who initiated this project together. ${ }^{24}$ However, from the very beginning, the Franco-German project faced heavy resistance from other European countries, especially those that were also members of the EC. On 15 December 1972, for instance, the Nine met to discuss the issue of "terrorism" and how to deal with it within the CoE framework. In this meeting it became clear that most states were sceptical about the real outcome of any discussion of terrorism in the CoE. It was only seen as a "stimulator," with other fora being better suited for addressing this

\footnotetext{
${ }^{20}$ It was adopted on 14 December 1973. The official title of the Convention is "The Convention on the Prevention and Punishment of Crimes against Internationally Protected Persons, including Diplomatic Agents".

${ }^{21}$ Vermerk Ref. IB 1: Massnahmen zur Vermeidung von Diplomatenentführungen, 17.07.1970, B20 499, PA.

${ }^{22}$ Draherlass an die Beobachtermission bei den VN, 14.09.1970, B30 499, PA.

${ }^{23}$ Memo Referat 200: Anti-Terrorismus-Konvention des Europarates, 22.07.1976, B83 982, PA; Memo

Politische Abteilung 2 an den Bundesminister: Haltung der Bundesregierung zur Anti-Terrorismus-Konvention des Europarats (EuR), 09.07.1976, ZA 111264, PA; Council of Europe, "Parliamentary Assembly Recommendation 684 (1972) on International Terrorism," (1972). http://www.coe.int/t/dlapil/codexter/Source/PA_Recommendation_684_1972_EN.pdf (accessed 06.03.2012). Council of Europe, "Committee of Ministers Resolution (74) 3 on International Terrorism," (24.01.1974). http://www.coe.int/t/dlapil/codexter/Source/CM_Resolution\%2874\%29_3_EN.pdf (accessed 06.03.2012). Vermerk: Zum Stand der internationalen Zusammenarbeit zur Bekämpfüng des Terrorismus, 02.02.1976, ZA 121071, PA; Memo: Denkschrift zu dem Übereinkommen, attached to Schnellbrief BMJ an das AA: Europäisches Übereinkommen vom 27. Januar 1977 zur Bekämpfung des Terrorismus, 09.09.1977, B83 1234, PA.

${ }^{24}$ National Foreign Assessment Center: International Issues Review, 30.03.1979, NLC-23-44-2-4-2, CIA FOIA, JCL.
} 
issue. ${ }^{25}$ For most EC countries, the UN was clearly the organisation of choice to deal with terrorism and the CoE was only to play a minor role. The Germans took this into account when determining their own position on further measures that the CoE should take. Although Bonn was in favour of the organisation playing a more active role, it also stressed that the CoE should focus on legal issues rather than on political matters pertaining to terrorism. Most EC member states, such as France and Italy, shared the German stance. ${ }^{26}$ Consequently, once this compromise was reached on 18 January 1973, the CoE decided to establish an ad hoc committee to "examiner [...] les aspects juridiques des problèmes posés par le terrorisme international." ${ }^{27}$ A parallel Austrian proposal to also deal with the political issues related to terrorism did not gain the necessary approval, ${ }^{28}$ which again underlined the preference of member states to limit themselves to purely legal matters. The discussions of the ad hoc committee soon made it clear that the most important - and contested - legal issues related to terrorism that the CoE should address were related to extradition and exceptions for political offenders from extradition agreements. Despite this, during the sessions in March 1973, the German side noted a "general lack of enthusiasm to seek a solution to the terrorism problem within the framework of the Council of Europe." The CoE members were not very committed to dealing with terrorism in the intra-European setting the CoE provided. This was reflected in the statements of the ad hoc committee itself, which remarked that the UN would be the more appropriate institution to deal with the issue of terrorism. This is certainly one of the few cases in history where a commission considered itself incompetent to deal with a topic it had been charged with. Therefore, the CoE merely decided to implement a Belgian proposal to conduct another survey to gather information on the background and causes of terrorism in individual countries. The member states were also asked to report on their anti-terrorism legislation. ${ }^{29}$ But no measures going beyond that were decided. Even mounting US pressure to have the CoE take a more proactive stance on anti-terrorism efforts did not change the mood in Strasbourg. ${ }^{30}$

It was only against the backdrop of the stalemate situation at the UN - once the Diplomats Convention had been adopted and the consensus among UN members evaporated -

\footnotetext{
${ }^{25}$ Drahtbericht Ständige Vertretung Straßburg an das AA, 18.12.1972, ZA 121069, PA.

${ }^{26}$ Drahtbericht Ständige Vertretung Straßburg an das AA, 09.01.1973, ZA 121069, PA.

${ }^{27}$ Drahtbericht Ständige Vertretung Straßburg an das AA, 18.01.1973, ZA 121069, PA.

${ }^{28}$ Drahtbericht Ständige Vertretung Straßburg an das AA, 09.01.1973, ZA 121069, PA.

${ }^{29}$ Protokoll: Bekämpfung des internationalen Terrorismus, 21.03.1973, ZA 121069, PA.

${ }^{30}$ Briefing Memorandum From the Special Assistant to the Secretary of State and Coordinator for Combating Terrorism (Hoffacker) to Secretary of State Kissinger, Washington, October 4, 1973; RG 59, M/CT Files: Lot 77 D 30, Secretary-Correspondence and Reports 1972-73, US National Archives (USNA).
} 
that the CoE became concerned with terrorism again in a more direct way. ${ }^{31}$ Given their experience at the UN, in 1974 the Germans shifted their primary attention away from the world body and back to European institutions, such as the EC and the CoE, in order to deal with terrorism. ${ }^{32}$ Consequently, Germany's Minister of Justice Vogel pushed for a working group on terrorism to be established, which translated into the Council of Ministers' Resolution (74) 3 of 24 January 1974. During its meeting on 6 to 8 October 1975, this working group created a special ad hoc committee to elaborate a draft convention against terrorism. ${ }^{33}$ At the same time, the hostage crisis at the Organization of Petroleum Exporting Countries in Vienna in December 1975 further motivated the $\mathrm{CoE}$ to come up with presentable results. ${ }^{34}$ The ad hoc committee had its first session in December 1975. It produced a draft text that was discussed by the working group from 2 to 6 February 1976. During these negotiations, which lasted several days and were extremely cumbersome, the draft underwent significant changes and finally managed to define criminal acts where the political offence exception did not apply (Article 1). Moreover, Article 2 enabled states to also include other serious criminal acts in the category of extraditable crimes. In addition, Articles 6 and 7 obliged the parties to the convention to establish jurisdiction over certain defined acts and to make their authorities prosecute these acts if they did not extradite the offenders. In short, the text centred upon the principle of "aut dedere aut iudicare" (extradite to try) - with the emphasis being on extradition. Finally, Article 8 provided for judicial assistance between states in cases of terrorism, which was a novelty. While these measures served to reduce the worst abuses of the political exceptions to extradition, the Germans were not entirely happy with the result. For Bonn, the fact that countries could still exclude certain cases from extradition was not satisfactory (Art. 5 and 13). The German attempt to criminalise and depoliticise all terrorist acts hence failed, as the Federal Ministry of Justice itself recognised. There were still cases where states could invoke exemptions to not extradite terrorists. Nevertheless, in spite of its shortcomings, the Ministry of Justice still considered the draft a "useful solution." 35 The advantage now was that even if a country refused to send a perpetrator back to a country asking for his or her extradition, it would be obliged to try the

\footnotetext{
${ }^{31}$ See Blumenau, "The United Nations and West Germany's Efforts against International Terrorism in the 1970 s," 73.

${ }^{32}$ Memo: Haltung der Bundesrepublik Deutschland, attached to Memo Ref. 511 an das Ref. 230: Vorbereitung der 29. Generalversammlung der Vereinten Nationen, 15.08.1974, B83 825, PA.

${ }^{33}$ Schnellbrief BMJ an das Bundeskanzleramt etc, 02.03.1976, ZA 121074, PA.

${ }^{34}$ Report CIA: Political Perspectives on Key Global Issues, March 1977, NLC-132-64-1-1-2, CIA FOIA, JCL.

${ }^{35}$ Schnellbrief BMJ an das Bundeskanzleramt etc, 02.03.1976, ZA 121074, PA.
} 
suspect itself. It would no longer be possible for terrorists to escape punishment. That was indeed an important step forward.

Once consensus was reached on the actual content of the Convention, the question of whether or not the Convention should be open to non-member states caused some controversy. The majority of the delegations wanted this to be an exclusive CoE Convention, while France and others such as Sweden, Greece, and Denmark wanted to open it to countries outside of the CoE. The Director of Legal Affairs of the CoE, Heribert Golsong, a German citizen, pointed out that this would raise serious problems as it would be possible for certain non-democratic, i.e. Soviet bloc, countries to ratify the Convention with the express purpose of exploiting it to their own ends. ${ }^{36}$ For Bonn, it was clear that the Convention should be limited to only CoE member states, in large part to avoid applying the Convention to East Germans trying to escape from the GDR which would have to be returned to East Germany if the country were a party to the convention. Therefore, the Ministry of Justice noted that:

As a consequence of the particular scope of the commitment deriving from the Convention which necessitates mutual trust, the Convention is only open for members of the Council of Europe. [...] Because of the basis of [shared values and principles] the Council of Europe members have equal interests and the necessary mutual trust to cooperate in the fight against serious crimes committed on their territory even when the offenders have political motives or claim to have them. ${ }^{37}$

As no final decision could be reached, it was left to the committee of ambassadors to find a solution. ${ }^{38}$ In subsequent meetings, the German view dominated and it was decided that the Convention would only be open to signature for member states of the $\mathrm{CoE}$ and not to others. ${ }^{39}$

\section{The French Veto}

On 25 June 1976, all obstacles appeared removed and the Meeting of the Ministers' Deputies met to adopt the Convention but, quite surprisingly to everybody, France vetoed it. ${ }^{40}$

\footnotetext{
${ }^{36}$ Memo: project de convention européenne sur la repression du terrorisme, (Concl (76) 255/XV), no date, probably spring 1976, ZA 119485, PA.

${ }^{37}$ Memo: Denkschrift zu dem Übereinkommen, attached to Schnellbrief BMJ an das AA: Europäisches Übereinkommen vom 27. Januar 1977 zur Bekämpfung des Terrorismus, 09.09.1977, B83 1234, PA. P. 6.

${ }^{38}$ Memo: project de convention européenne sur la repression du terrorisme, (Concl (76) 255/XV), no date, probably spring 1976, ZA 119485, PA.

${ }^{39}$ Memo: Denkschrift zu dem Übereinkommen, attached to Schnellbrief BMJ an das AA: Europäisches Übereinkommen vom 27. Januar 1977 zur Bekämpfung des Terrorismus, 09.09.1977, B83 1234, PA.

${ }^{40}$ Letter BMI an das AA: Maßnahmen zur Bekämpfung des internationalen Terrorismus im EG-Bereich, 02.08.1976, ZA 119485, PA.
} 
Allegedly, the Convention did not go far enough for Paris. ${ }^{41}$ As Interior Minister Michel Poniatowski explained to his German counterpart Werner Maihofer, the French considered the Convention to be inadequate as there were still too many loopholes in the text. The fact that countries could either extradite or try a suspect themselves would not ensure that terrorists would always be punished sufficiently. According to him, France was in favour of a strict obligation to extradite and a tougher convention. ${ }^{42}$ Bonn was astonished and concerned about the French veto. For the AA, it clearly had the potential to drive a wedge between the member states of the CoE and could possibly be the kiss of death for the convention. Moreover, it threatened the three-level approach that Germany was pursuing on international terrorism: first at the CoE level; but also, second, at the level of the EC where plans against terrorism were discussed among the Nine within the Trevi network; and finally at the UN level. The political analysts at the AA also warned that the failure of the Convention would have negative repercussions among public opinion both in Germany and worldwide. If more or less like-minded European countries were unable to find common denominators in the fight against terrorism, how would it be possible on a global scale that was far more diverse? With the French veto, and thus one of the most important European countries not supporting the Convention, its implementation was deemed impossible. In another meeting between the Ministers of the Interior, Poniatowski suggested a compromise: France would sign the Convention if a special clause was included that obliged EC members to conclude another agreement with stricter stipulations. Maihofer was not enthusiastic at the prospect of new negotiations about the text of the Convention and merely "took note of this information." In a meeting between the foreign ministers, during which the Convention was also discussed, Jean Sauvagnargues also promised to reconsider the French position. The political director of the AA, Günther van Well, consequently advised Genscher to give the French some time to think things over and work out their strategy. ${ }^{43}$ But behind closed doors, the Germans were not convinced that Paris' motivation was the loopholes in the Convention and speculated as to the actual reasons - but they were unable to find a convincing explanation for the behaviour of the French. ${ }^{44}$ It was therefore difficult for Bonn to design a strategy for dealing with Paris

\footnotetext{
${ }^{41}$ Letter Ständige Vertretung beim Europarat an das AA, 25.06.1976, ZA 121074, PA; Drahtbericht Ständige Vertretung beim Europarat an das AA, 25.06.1976, ZA 121074, PA; Letter Politische Abteilung 2 an den Bundesminister: Haltung der Bundesregierung zur Anti-Terrorismus-Kovention des Europarats (EuR), 09.07.1976, ZA 121074, PA.

${ }^{42}$ Vermerk Ref. 230: Deutsche VN-Initiative gegen Geiselnahme, 08.09.1976, B83 1236, PA.

${ }^{43}$ Letter Politische Abteilung 2 an den Bundesminister: Haltung der Bundesregierung zur Anti-TerrorismusKonvention des Europarats (EuR), 09.07.1976, ZA 121074, PA.

${ }^{44}$ Memo Referat 200: Erste Konferenz der für Sicherheitsfragen zuständigen Minister der EG-Staaten in Luxemburg am 29.06.1976, no date, probably late June 1976, ZA 121074, PA.
} 
when its motives remained obscure. To appease France, however, a compromise could be reached at the EC. During a meeting of the European Council on 12 and 13 July 1976, the idea of a special agreement among EC members concerning extradition was discussed to show some goodwill towards Paris. ${ }^{45}$ No decision was reached, but this was meant as a signal to France that its concerns were taken seriously. This also meant though that the anti-terrorism negotiations at the $\mathrm{CoE}$ and EC where now officially linked. France's condition to only allow the $\mathrm{CoE}$ Convention to be adopted if negotiations about terrorism started at the EC bore some fruits. The day after the European Council, van Well asked the German embassy in Paris to enquire with the Quai d'Orsay if - in view of the recent EC discussions on extradition - Paris would now be willing to withdraw its veto and thus pave the way for an implementation of the Convention. The AA was especially concerned about the negative repercussions that a French veto might have on cooperation with the other CoE members. ${ }^{46}$ It was crucial for the German three-level policy on terrorism that the Convention enter into effect, as it was a vital pillar that was supposed to complement the other efforts going on at the EC level and at the UN level. ${ }^{47}$ But the French position remained extremely vague and contradictory. At first, Paris had claimed that the Convention did not go far enough in obliging countries to extradite criminals. During the enquiries conducted by Bonn's diplomats, however, it seemed that France had a problem with the general obligation to extradite as enshrined in the draft convention. This was a shift of positions by 180 degrees. It now seemed that Paris did not want to have an obligation to extradite in the text altogether. As a French official explained to the German chargé d'affaires, "the Ministry of the Interior would, for instance, never agree to extradite 'terrorist' Armenians to Turkey." 48 It was indeed difficult to make sense of the French position at the time and this posed a problem for Bonn and for its policy at the CoE. By September 1976, after there had been some reshuffling in the French cabinet, two possible options were emerging that could help to solve the tricky situation: either changing the extradition clause or a withdrawal of the French veto but without France joining the Convention. ${ }^{49}$ Both solutions were potentially dangerous though. If France initiated the renegotiation of the extradition clause and the exceptions to it, Pandora's Box would be opened again and the Convention could possibly never see the light of day; or - equally bad -

\footnotetext{
${ }^{45}$ Runderlass, 14.07.1976, ZA 121074, PA; Letter Referat 200 an das Bundeskanzleramt etc: Bekämpfung des internationalen Terrorismus, no date, probably 15 July 1976, ZA 121074, PA.

${ }^{46}$ Drahterlass an die Botschaft Paris, 14.07.1976, ZA 121074, PA.

${ }^{47}$ Memo Referat 200: Erste Konferenz der für Sicherheitsfragen zuständigen Minister der EG-Staaten in Luxemburg am 29.06.1976, no date, probably late June 1976, ZA 121074, PA.

${ }^{48}$ Drahtbericht Botschaft Paris an das AA, 07.09.1976, ZA 121074, PA.

${ }^{49}$ Drahtbericht Botschaft Paris an das AA, 07.09.1976, ZA 121074, PA.
} 
the negotiations could go on forever and the final product would be so watered down that its actual effect would be marginal. Likewise, if France - as one of the biggest and most important European and global players - did not sign the Convention, there would no longer be a strong showing of European unity and determination to fight terrorism that Bonn was striving for. Not surprisingly though, these two options did not find much approval in Bonn and the discussions between the capitals continued. During the consultations of the French and German political directors on 22 September, France informed Germany of its intention to sign the Convention if Paris could include reservations pertaining to the Basque Question. This proposal only received a lukewarm reception in Bonn. The Germans were concerned that this would weaken the Convention and might encourage other states to make new demands as well. ${ }^{50}$ The negotiations continued into the autumn while at the same time West Germany launched its first UN initiative which was supposed to lead to a convention against the taking of hostages. ${ }^{51}$ Bonn made several demarches at the Quai d'Orsay and Genscher also addressed the issue of the French veto on several occasions with his French counterpart. All of this was to no avail however. The Germans tried to convince the French that the damage would actually be worse if the Convention was adopted with these shortcomings rather than if it was not adopted at all. But Bonn was suspicious that Paris had ulterior motives dictating its policy on the Convention. ${ }^{52}$ Much like West Germany, which needed the Convention for its global anti-terrorism strategy and as a signal to the UN that negotiations on the Hostages Convention should be sped up, Paris also viewed the Convention as an element of its larger global policy. Finding the actual driving forces behind France's policy was vital for the Germans if they were to find a solution to the dilemma at the CoE. Paris' stance, however, remained ambiguous and puzzling. As an internal AA assessment noted with some anger and frustration:

The French stance on international agreements on fighting terrorism remains ambiguous and contradictory. On the one hand, they are open-minded regarding our UN initiative and have suggested themselves an agreement between the Nine. On the other hand, they resist any practical implementation especially of the Council of Europe Convention which has a model character

\footnotetext{
${ }^{50}$ Drahterlass an die Ständige Vertretung beim Europarat, 29.09.1976, ZA 121074, PA.

${ }^{51}$ This West German project was officially introduced to the UN in September 1976 and the - very cumbersome - negotiations went on for three years until a convention was adopted in December 1979. The UN project was the clear priority for Bonn because it was supposed to achieve a consensus among the international community on a very important aspect of terrorism and close existing gaps in international law. Moreover, the initiative was supposed to demonstrate Germany's increased political power, matching its economic strength. That was why the project quickly turned into a prestige project that could not be allowed to fail. For more information see Blumenau, "The United Nations and West Germany's Efforts against International Terrorism in the 1970s," 7679.

${ }^{52}$ Memo Ref. 200: Internationale Bekämpfung des Terrorismus, 07.09.1976, ZA 111264, PA.
} 
as it is the only fully formulated draft so far. It is not unlikely that they will continue to 'stonewall' by inventing ever new reasons as symbolic international agreements do not fit into their foreign policy (when it comes to the discreet and efficient police cooperation in fighting terrorists they are much more cooperative and interested). ${ }^{53}$

Towards the end of September 1976, France made another attempt to renegotiate the reservation clauses of the Convention to then be able to withdraw the veto. ${ }^{54}$ The AA was sceptical of this plan and the further developments justified their concerns: when the official French motion was presented to the $\mathrm{CoE}$, other states such as Ireland also wanted to push for modifications. ${ }^{55}$ The German government now had two options. The AA could accept the modifications demanded by France in order to obtain the French signature on the Convention. This would change the text of the Convention again, something Bonn was not very keen on, but it would allow the Convention to be adopted and it would send the strong signal to the UN that West Germany desperately wanted. Or, Bonn could insist on the more rigid Convention as it stood and reject calls for renegotiation at the risk of it never entering into force and sending a signal of disunity to New York. Moreover, by now this conflict had reached the point where it seriously endangered future European cooperation on the matter. ${ }^{56}$ Clearly, there was no real choice for the Germans; the only way to ensure the adoption of an instrument at all and to maintain the impression of European unity on the terrorism issue was to swallow the bitter pill of French modifications to the Convention text so that it could be passed. For the time being, however, the AA tried to find a middle way. The German representative in Strasbourg was instructed to make a statement saying that the federal government was against a reopening of negotiations of the text of the Convention. If France insisted on this procedure, it would have to provide a detailed list of the modifications it wanted for this idea to even be considered. However, Bonn maintained that it was interested in a solution to the problem and would be willing to further cooperate with France. While the representative was to take a firm stance on the issue of new negotiations, the German position was not actually so inflexible. As a matter of fact, the secret instructions given to Bonn's man in Strasbourg implied that Bonn could eventually agree to French wishes for modifications in order to have Paris withdraw its veto. This, however, was not to be revealed at this stage. In

\footnotetext{
${ }^{53}$ Memo Ref. 200: Ausführung des Beschlusses zur Terrorismus-Bekämpfung des Europäischen Rats vom 13.07.1976, 21.09.1976, ZA 111264, PA.

${ }^{54}$ Memo Referat 202: Deutsch-französische Direktorenkonsultation am 22. Sept. 76 in Bonn, 22.09.1976, B83 982, PA; Memo D5 an das Ref. 511: Anti-Terrorismus-Konvention des Europarates, 23.09.1976, B83 982, PA.

${ }^{55}$ Memo Ref. 511 an Herrn D5: Anti-Terrorismus-Konvention des Europarates, 27.09.1976, B83 982, PA; Drahtbericht Ständige Vertretung beim Europarat, Strassburg an das AA, 30.09.1976, B83 982, PA.

${ }^{56}$ Schnellbrief AA an das BMJ: Anti-Terrorismus-Konvention des Europarats, 04.10.1976, B83 982, PA.
} 
addition, it was determined that the Irish should also be approached informally to discourage them from pushing for any more modifications. ${ }^{57}$ This shows clearly that a decision had already been made that if France insisted only on the modifications mentioned earlier, Germany would agree in order to have the Convention enter into force. The statements that the representative was to make in Strasbourg were aimed at discouraging other states from also asking for modifications and to make it clear to France that it should minimise the scope of the changes it proposed. The backdoor out of the negative stance taken so far was already provided for in the German statement at the $\mathrm{CoE}$, in which Bonn insisted on the necessity of having France on board. The urgency that the AA attached to the whole matter was also mirrored in the fact that the Chancellor's Office was kept up to date on the whole issue. To further discourage any other country from also making modifications, Genscher informed his Irish counterpart directly that Germany would not support Irish endeavours to modify the Convention text. ${ }^{58}$ This was clearly second class treatment and not the equality among European countries that was always heralded. While France could rewrite the text, Ireland could not. This discrimination by Bonn illustrates the importance they attached to French participation - at almost all costs. In their eyes, France was a country that was simply too important to be left out of the framework. Certainly, one reason for this policy was the fact that France was a hub for terrorists or people who the Germans accused of supporting terrorists such as Abu Daoud or Klaus Croissant. ${ }^{59}$ Another reason was the important role that France played at the UN, as one of the five veto powers. If France did not join the $\mathrm{CoE}$ Convention, what credible arguments would Bonn have to ask other countries in New York to join its efforts to negotiate a UN convention against hostage taking?

Finally, in mid-October 1976, the German policy line openly shifted towards a softer approach to Paris' wishes for modifications. During a test vote at the CoE, 11 states voted in favour of the modifications suggested by France - including Germany - with two opposing (Belgium and Switzerland), and several countries abstaining. The Irish proposal for a modification of the text did not find a majority. ${ }^{60}$ The German and French political directors discussed the situation in Strasbourg during their consultations, three days later on 25 October

\footnotetext{
${ }^{57}$ Drahterlass an die Ständige Vertretung in Strassburg, 11.10.1976, B83 982, PA.

${ }^{58}$ Memo Abteilung 2 an BM Genscher: Europäische Konvention zur Bekämpfung des Terrorismus, 13.10.1976, B83 982, PA.

${ }^{59}$ Abu Daoud was the alleged mastermind behind the Munich attacks of 1972 and lived in Paris, see Thomas Riegler, Im Fadenkreuz: Österreich und der Nahostterrorismus 1973 bis 1985, ed. Oliver Rathkolb, Zeitgeschichte im Kontext (Wien: V\&R Unipress, Vienna University Press, 2011), 422.

${ }^{60}$ Draft letter Bundesminister des Auswärtigen an den Bundesminister des Inneren, attached to Memo Abteilung 2 an den Herrn Bundesminister: Übereinkommen des Europarats zur Bekämpfung des Terrorismus, 22.10.1976, B83 982, PA.
} 
1976. Laboulaye promised that France would negotiate with Brussels and Bern to get these states to refrain from voting against the Convention so that it could finally be adopted. At the same time, though, the French also stressed that they had a major interest in an EC extradition agreement and that this would actually be more important to Paris than the European Convention on the Suppression of Terrorism. ${ }^{61}$ This statement clearly indicated a shift in French attention away from the $\mathrm{CoE}$ and towards further cooperation among EC members. This swing in policy, while implying rough times at further EC meetings, also paved the way for an eventual withdrawal of the French veto. In order to prepare the final vote on the Convention and its modification, a meeting was convened by the legal counsellor of the $\mathrm{CoE}$, Golsong, on 26 October to discuss subsequent steps with the Belgian, Swiss, Austrian, and German representatives. During this meeting it appeared that French pressure in Brussels had been successful as the Belgian representative declared that in light of the need for the Convention to become effective, his country would refrain from vetoing it. The German side rejoiced as there was now finally the possibility of the Convention being adopted unanimously, which would finally send the clear signal that Bonn had hoped for and which they felt was necessary. At this important and final stage, the AA did not want to take any more chances. To avoid any last minute surprises, German embassies in $\mathrm{CoE}$ member states were instructed to call on the host governments and make sure that they would cooperate. Moreover, to discourage any ad hoc wishes for modifications and to put a good face on the matter, Germany made a statement in Strasbourg lamenting the necessity of the French modifications and expressing their conviction that this should not lead to a watering down of the intention of the Convention. ${ }^{62}$

Finally, success was within reach. During the vote on 10 November 1976 all but one state voted in favour of the adoption of the Convention - Ireland abstained. ${ }^{63}$ Dublin justified its abstention with its constitutional obligation to respect international law. According to the Irish interpretation, there would be a conflict between the Convention's obligation to extradite perpetrators and the prohibition, in international customary law, to extradite people accused of political offences. The legal department of the AA doubted the validity of this statement but Ireland maintained its decision to abstain, which nevertheless allowed the Convention to be

\footnotetext{
${ }^{61}$ Drahtbericht Botschaft Paris an das AA, 26.10.1976, B83 982, PA.

${ }^{62}$ Drahterlass an die Botschaften Athen, Bern, Brüssel, Dublin, Lissabon, Rom, Wien, Ständige Vertretung beim Europarat Strassburg, 03.11.1976, B83 982, PA.

${ }^{63}$ Drahtbericht Ständige Vertretung Strassburg an das AA, 10.11.1976, B83 982, PA.
} 
passed. ${ }^{64}$ While the text of the Convention had been adopted, the next step was to ensure that all countries ratified it quickly.

\section{The Ratification Process}

On 27 January 1977, the Convention was signed by the foreign ministers in Strasbourg and the German government spokesman heralded that "the federal government considers the Convention, after all, as an important as well as necessary contribution to the fight against international terrorism." ${ }^{\prime 65}$ One can almost hear the sigh of relief in this statement.

Still, the passing of the Convention came at a price: Norway, Italy, Portugal, and France made reservations concerning the extent of their obligation to extradite. The French minister announced at the same time that France would only ratify the Convention once an extradition agreement was adopted by the EC member states according to French wishes. The German representative to the CoE, Carl Heinz Lüders, already alluded to the fact that this agreement would probably never materialise since - given past experiences with Paris' ambiguous policies - the French government themselves would oppose it in the end. ${ }^{66}$ Obviously, Paris tried to make a link between the negotiations in the EC and the antiterrorism efforts of the $\mathrm{CoE}$ to quite frankly blackmail its EC partners to quickly adopt an extradition agreement at the EC level. However, the difference now was that the Convention had been adopted so once it had a sufficient number of ratifications it would enter into force. The French statement was serious since it suggested that one of the biggest European countries might not ultimately ratify the Convention. Nonetheless, it did not have the same devastating implications that a French veto of the text would have had. For the AA, the motivation behind France's statement was once again a puzzle and Bonn suspected the French of catering to some unspecified wishes of Arabs and Palestinians. ${ }^{67}$ French behaviour actually supported this conclusion, as indicated by the recent French rejection of West Germany's extradition request for the instigator of the Munich attacks in 1972, Abu Daoud. ${ }^{68}$ Another

\footnotetext{
${ }^{64}$ Brief Botschaft Dublin an das AA: Europäisches Übereinkommen zur Bekämpfung des Terrorismus, 18.11.1976, B83 982, PA. See also Brief BMJ an das AA: Europäisches Übereinkommen zur Bekämpfung des Terrorismus, 03.01.1977, B83 982, PA. Indeed, the reason given by Dublin does not seem to be convincing as, under the Convention, countries could refuse to extradite offenders as long as they tried them themselves. ${ }^{65}$ Sprechzettel für den Regierungssprecher, attached to Schnellbrief BMJ an das AA: Europäisches Übereinkommen vom 27. Januar 1977 zur Bekämpfung des Terrorismus, 09.09.1977, B83 1234, PA. P. 3 ${ }^{66}$ Brief Ständige Vertretung Strassburg an das AA: Unterzeichnung der Konvention zur Bekämpfung des Terrorismus, 03.02.1977, B83 982, PA.

${ }^{67}$ Brief Ständige Vertretung Strassburg an das AA: Unterzeichnung der Konvention zur Bekämpfung des Terrorismus, 03.02.1977, B83 982, PA.

${ }^{68} \mathrm{Abu}$ Daoud was arrested in Paris and both Israel and Germany requested his extradition to stand trial for allegations about having planned the Munich attacks. However, in record-breaking time, the French rejected the
} 
theory suggested that the French reservation was also a consequence of the French Constitution, which paid special attention to granting political asylum and was a result of France's long history of political freedom. ${ }^{69}$ The AA also suspected that France's stance was based on domestic considerations. But these were all just guesses. An unsatisfactory official French explanation was given by Foreign Minister Louis de Guiringaud who told Genscher that "there are countries in the Council of Europe who could consider terrorist attacks aspects of struggles for liberation. The political understanding of the signatories is simply not the same." $" 70$ But the Germans doubted this was the real reason. The only thing that was obvious was that Bonn did not know why Paris took this stance, which caused a great deal of frustration at the AA. In hindsight, the French position is clearer. As some scholars argue, the French government deliberately turned a blind eye to terrorists living in France as long as they did not plan attacks against France or French interests. Therefore, an obligation to try or extradite them would have worked against what Jeremy Shapiro and Bénédicte Suzan call the "sanctuary doctrine". ${ }^{71}$ The moment when the French started abandoning this policy on terrorists within France also coincides with the ratification of the Convention in 1987.

In November 1977, more than half a year after the signature of the Convention, France still did not show any inclination of ratifying it anytime soon. Rather, the AA noticed that "the Convention was, and still is occasionally, criticised in the French and Italian press with partly explicit anti-German nuances. These tendencies have recently increased rather than

Israeli request (Tel Aviv having allegedly no right to seek extradition) and the West German request (Bonn's request not being properly formulated) and let him leave France for Algeria. Both West Germany and Israel protested and criticised the French decision, see Memo "Abu Daoud Affair", no date, FCO 58/ 1130, UKNA. See also James F. Clarity, "French Court Frees Terrorists Suspect. He flies to Algeria," The New York Times, (12.01.1977), A1: A1.

${ }^{69}$ Friedlander, "Terrorism and International Law: Recent Developments," 501, 502.

${ }^{70}$ Niederschrift D2 über dt.-frz. AM-Konsultationen, 16.6.1978, no date, probably 14.06.1978, ZA 112906, PA.

${ }^{71}$ See Jeremy Shapiro and Bénédicte Suzan, "The French Experience of Counter-terrorism," Survival 45, no. 1 (2003), 67-98: especially pp. 69-70. On the French encounter with terrorism see also Shaun Gregory, "France and the War on Terrorism," Terrorism and Political Violence 15, no. 1 (2003), 124-147. For the lenient position of the French authorities on terrorists not attacking France in the 1970s see especially p. 130. For more information on the French encounter with terrorism and the reactions to it, see Edward Moxon-Browne, "Terrorism in France," in The Threat of Terrorism, ed. Juliet Lodge(Brighton: Wheatsheaf Books, 1988), 213 228; Nathalie Cettina, "The French Approach: Vigour and Vigilance," in Confronting Terrorism. European Experiences, Threat Perceptions and Policies, ed. Marianne van Leeuwen, Nijhoff Law Specials (The Hague, London, New York: Kluwer Law International, 2003), 71-94: especially pp. 75, 78-85. When French citizens were attacked abroad, the government took a much stronger and rigid position towards the terrorists. For an infamous example, the "Claustre Affaire", see Nathaniel K. Powell, "The 'Claustre Affair': A Hostage Crisis, France and Civil War in Chad, 1974-1977," in An International History of Terrorism. Western and Non-Western Experiences, ed. Jussi M. Hanhimäki and Bernhard Blumenau(Oxon: Routledge, 2013), 189-209. The "Polisario" crisis of late 1977 is another example, when French mining experts were abducted by rebels in Western Sahara, see "France Protests Detention of Six by Polisario Rebels in the Sahara," The New York Times, (24.05.1977), 4. 
decreased."72 Consequently the Germans did not have much of a choice other than "avoiding the impression that the Convention is a result particularly of German efforts and interests as this would rather reduce the chances that it will be soon ratified by as many countries as possible." ${ }^{73}$ Meanwhile, France kept insisting that it would only ratify the Convention once the EC had agreed on a general extradition agreement. ${ }^{74}$ The statement above also reveals something else. In broad parts of Europe, German efforts, especially in the field of counterterrorism, were still viewed with suspicion. The image of the "ugly German" had not disappeared. This explains the extent to which the federal government was playing down its role in the genesis of the Convention in order not to jeopardise its ratification. The very fact that this assessment was voiced only a month after the successful release of German hostages on board a Lufthansa jet in Mogadishu carried out by the German GSG 9 counter-terrorism unit - and the suicides in Stammheim - points to the deep rooted mistrust that still existed about Germany's intentions in many neighbouring countries. ${ }^{75}$ Consequently, while the Convention was now formally adopted and signed it still remained questionable as to how many countries would actually ratify it and therefore apply it.

\section{Success AT LASt: The Convention EnTERS INTO ForCE}

On 3 May 1978 the FRG was the third state to deposit the instrument of ratification, after Sweden and Austria, which allowed the Convention to enter into effect three months later. France maintained its rejection to ratify it. ${ }^{76}$ However, the years of negotiations exhausted Germany's interest in further anti-terrorism efforts at the CoE. Quite obviously, the European Convention was as far as the European countries would go in anti-terrorism cooperation. When plans were floated, in the summer of 1978, for the CoE to also deal with direct measures to fight terrorism, the German and British Ministers of the Interior, Gerhart Baum and Merlyn Rees, swiftly dismissed this proposal and agreed that the CoE should only focus on legal questions and leave other aspects to more appropriate organisations. ${ }^{77}$ At a meeting

\footnotetext{
${ }^{72}$ Memo: Europäisches Übereinkommen zur Bekämpfung des Terrorismus, attached to Memo: Ref. 200: Terrorismusbekämpfung, 14.11.1977, B83 1234, PA.

${ }^{73}$ Ibid.

${ }^{74}$ Ibid.

${ }^{75}$ For more information on the Lufthansa jet "Landshut" crisis see Tim Geiger, "Die "Landshut" in Mogadischu. Das außenpolitische Krisenmanagement der Bundesregierung angesichts der terroristischen Herausforderung 1977," Vierteljahreshefte für Zeitgeschichte 57, no. 3 (2009), 413-456.

${ }^{76}$ Letter Ständige Vertretung beim Europarat an das AA: Europäisches Übereinkommen zur Bekämpfung des Terrorismus, 03.05.1978, B83 1234, PA.

${ }^{77}$ Memo Ref. IS 1: Besuch des britischen Innenministers am 3. und 4. September 1978 in Bonn, 04.09.1978, attached to Letter BMI an das AA: Besprechungen mit dem britischen Innenministers am 3. und 4. September 1978 in Bonn, 13.09.1978, B83 1235, PA.
} 
of the Committee of Ministers' Deputies, no majority could be found for further cooperation between the judiciary and police forces of the member states. The most fervent opponents were Great Britain, France, Belgium, and the Netherlands, with Austria, Italy, and Switzerland in favour. Germany took a middle-of-the-road stance and alluded to the possibility of supporting the idea if it significantly went beyond what had been decided by the CoE already. The Germans favoured an idea developed by the French delegation that the ministers should not issue a declaration but only make the text part of a press communiqué. ${ }^{78}$ This was an attempt by the Germans to avoid appearing as the opponents of another antiterrorism initiative while at the same time they did not see much value in it and certainly did not favour the idea. As the talks between Rees and Baum suggested, Bonn was actually against this project but for the sake of public perception the AA apparently did not see itself in a position to openly reject it. The Germans, voluntarily or not, assumed the same strategy that France had pursued during most of the negotiations on the Convention. Bonn's unfavourable stance is, in fact, not surprising. When the idea for this new initiative came up, Germany was heavily involved in simultaneous negotiations at the UN and the EC so it was hardly willing to take up yet another project.

Similar attempts to have a meeting of the CoE Ministers of the Interior to discuss issues pertaining to domestic security were re-launched in 1979. Once again, the German government and most other EC members were not convinced of the usefulness of a $\mathrm{CoE}$ meeting in addition to the EC meetings going on simultaneously on similar matters, so the suggestion was not adopted. ${ }^{79}$ Germany's focus on the European level had by now shifted away from the CoE and towards the EC. France and Germany had made a package deal that France would withdraw its veto over the Convention if parallel negotiations started among the EC member states on an extradition agreement. This agreement was supposed to make the CoE Convention applicable in full to all EC member states. Those EC negotiations culminated in the Dublin Agreement, which was adopted in 1979 but never entered into effect. $^{80}$

\footnotetext{
${ }^{78}$ Letter Ständige Vertretung Straßburg an das AA: TOP 16, no date, probably 24.10.1978, B83 1235, PA.

${ }^{79}$ Drahterlass an die Ständige Vertretung Straßburg, 21.02.1979, B83 1235, PA; Vermerk: Ständige Vertretung Straßburg: Anlage 10 zum Bericht Nr. 311 vom 30.04.1979, B83 1235, PA.

${ }^{80}$ For the package deal see for instance: Memo Ref. 200: Terrorismus-Erklärung des Europäischen Rats vom 13.07.1976, 09.12.1976, B83 982, PA; Memo Ref. 200: Ausführung der Erklärung des Europäischen Rats vom 13.07.1976 zum internationalen Terrorismus, 06.01.1977, ZA 121077, PA. The negotiations also became extremely tedious as France tried to link the Dublin Agreement with negotiations for a common legal space or "espace judiciaire européen" to which most of the other EC members objected, see for instance Memo Ref. 202 an das Ref. 511: Französischer Vorschlag eines einheitlichen europäischen Rechtsraumes, 20.12.1977, B83 1236, PA; Memo Ref. 200: Terrorismusbekämpfung, 03.02.1978, B83 1236, PA; Memo Unterabteilungsleiter II B (BMJ): Europäischer Rechtsraum, 26.03.1980, ZA 122712, PA. On the EC efforts against terrorism in the
} 
By the late 1970s, several countries had issued reservations when ratifying the Convention. These reservations were thoroughly checked by the AA to see if they watered down the Convention too much and hence needed to be opposed. Consequently, the Belgian, Norwegian, and Portuguese reservations not only faced resistance from Bonn but also from London and led to joint British-German efforts to have the countries withdraw them. The argument was that by making reservations about the scope of cases that were exempted from extradition, these reservations were inadmissible as they would conflict with the basic intention of the Convention to abolish political offence exceptions. ${ }^{81}$ Therefore, the German mission at the $\mathrm{CoE}$ was instructed to support the British protests against the reservations. ${ }^{82}$ Subsequently, a modus of Anglo-German cooperation emerged that was indeed successful.

The outcome of the ratification process was very disappointing though. By early 1980, of the nine EC members, only Great Britain, Germany, and Denmark had signed and ratified the CoE Convention. ${ }^{83}$ While the negotiation of the Convention was a success story, at least in the end, the ratification process once again pointed to the difficulties of having countries subscribe to and enforce common measures against terrorism. The negotiation of the Convention was carried out between the governments, but the ratification of the document in most countries required parliamentary debate and approval. Achieving consensus on the right approach to terrorism was very cumbersome and the ratification process dragged on for a long time. The lengthy ratification process also highlights the fact that despite improvements, mutual trust among the signatories was still very fragile, experiences with terrorism differed greatly among the member states, and some countries still preferred bilateral counterterrorism cooperation. ${ }^{84}$ The signal that Bonn had hoped for was not so clear after all. However, to the federal government it did not matter so much anymore. Bonn could still

1970s see for instance Juliet Lodge, "Introduction - Terrorism and Europe: Some General Considerations," in The Threat of Terrorism, ed. Juliet Lodge(Brighton: Wheatsheaf Books, 1988), 1-28: 21-25; Antonio Vercher, Terrorism in Europe. An International Comparative Legal Analysis (Oxford: Clarendon Press, 1992), 352, 354356; Javier Argomaniz, The EU and Counter-Terrorism. Politics, Polity and Policies after 9/11 (Milton Park, Abingdon, Oxon: Routledge, 2011), 5-7.

${ }^{81}$ Memo Ref. 501 an das Ref. 511: Europäisches Übereinkommen vom 27. Januar 1977 zur Bekämpfung des Terrorismus, 28.12.1978, B83 1235, PA.

${ }^{82}$ Letter AA an die Ständige Vertretung Straßburg: Europäisches Terrorismus- Übereinkommen, 12.01.1979, B83 1235, PA; Memo Ref. 501 an das Ref. 511, 14.03.1980, B83 1437, PA.

${ }^{83}$ Memo Ref. 200: EPZ-Zusammenarbeit der neun EG-Staaten zur Bekämpfung des Terrorismus und zur Schaffung eines europäischen Rechtsraums, 28.01.1980, B83 1238, PA.

${ }^{84}$ While it goes beyond the scope of this article to elaborate on the experiences of individual countries with terrorism and the reactions to it, more information can be found, for instance in Juliet Lodge, ed. The Threat of Terrorism, ed. Brighton (Wheatsheaf Books, 1988); Marianne van Leeuwen, ed. Confronting Terrorism. European Experiences, Threat Perceptions and Policies, Nijhoff Law Specials, vol. 56 (The Hague, London, New York: Kluwer Law International 2003).

On some examples of Franco-Spanish or Anglo-Irish cooperation see for instance Vercher, Terrorism in Europe. An International Comparative Legal Analysis, 398-403. 
instrumentalise the Convention to show that the Europeans had done their homework and that it was now up to the UN to follow suit. By the time the Convention entered into force, significant progress had already been made at the UN on the Hostages Convention and the symbolic message from the European Convention on the Suppression of Terrorism was less urgently needed. For Bonn, while legal implications from the Convention were welcomed, the main goal behind the project was of a symbolic nature: the world (and for that matter also the German electorate as well as terrorists) was to see that European states were determined to improve their cooperation against terrorism.

\section{CONCLUSION}

The CoE was an important part of Germany's anti-terrorism efforts. It adopted a Convention that narrowed the existing loopholes in the European extradition system regarding political offences; but more importantly, it was also of symbolic importance for the most important and prestigious German anti-terrorism initiative against hostage-taking that was discussed at the UN. The AA primarily saw the CoE Convention as a tool to facilitate extradition between member states (and as such was more reactive), as opposed to the UN convention, which was aimed at fighting hostage-taking as such - and hence served a preventive purpose. ${ }^{85}$ The Convention was also a symbol that cooperation was possible and - likewise - that countries could agree on a modus vivendi to deal with the incredibly complex issue of terrorism and the aspects related to it such as the extradition of culprits. In that context, the CoE Convention was also a prestige project for Germany. It was meant to demonstrate that the Europeans could lead the way in dealing with important challenges and that Germany was successful in assuming leadership in these endeavours.

The practical relevance of the Convention, beyond the symbolic message it sent out, is more difficult to assess. Some legal scholars argue that the actual benefits of the Convention are close to naught because of the remaining possibility of refusing extradition of criminals based on Article 5 (if the country deemed a person to be prosecuted because of race, religion, nationality, or political opinion) and Article 13 (which allowed for reservations) of the Convention. ${ }^{86}$ However, it is worth reiterating that, although the Convention did not do away

\footnotetext{
${ }^{85}$ Memo Ref. 511: Hausbesprechung. Konvention gegen Geiselnahme am 23.02.1977, 10.30 Uhr, Saal 401, no date, probably 23. or 24.02.1977, B83 986, PA.

${ }^{86}$ For a discussion of the shortcomings of the Convention, especially with regard to Arts. 5 and 13 see for instance Lodge, "Introduction - Terrorism and Europe: Some General Considerations," 19-20; Otto Lagodny, "The European Convention on the Suppression of Terrorism. A Substantial Step to Combat Terrorism," University of Colorado Law Review 60, no. 3 (1989), 583-600; Mark B. Baker, "The Western European Legal Response to Terrorism," Brookly Journal of International Law 13, no. 1 (1987), 1-24: 5-8, 23; Malcolm
} 
entirely with the political offence exception, it at least symbolically intended to limit its scope and was thus an important signal as well as part of a broader development towards multilateral responses to terrorism. While it was still possible for countries to refuse extradition, now Articles 6 and 7 obliged them to try the suspects. Extradition should be the rule and failure to do so would still lead to the prosecution of the suspect, according to the Convention. ${ }^{87}$ As Otto Lagodny put it, the principle of "aut dedere aut iudicare" had changed into "primo dedere - secundo prosequi". ${ }^{88}$ Despite its shortcomings, the place of the Convention in the history of anti-terrorism still remains important. It demonstrates that several international and regional organisations - such as the UN, the EC and also the CoE - were involved in the fight against terrorism and some even managed to produce results. ${ }^{89}$ This was, however, as far as anti-terrorism negotiations at the CoE would go. The remaining issues especially those pertaining to practical day-to-day cooperation - had to be resolved by other institutions, such as the EC. The CoE restricted itself - or perhaps more accurately was restricted by the Germans and British - to legal matters.

The negotiations on the Convention point to a common interest among most European countries, especially those that were exposed to terrorism, such as Germany, Italy and the UK, in limiting the scope of the political exception safeguard. ${ }^{90}$ By the time of the ratification process, the UK had even become a forerunner, together with Germany, in assuring that the reservations made by the signatories remained within reason. In contrast to the compromising stances of most of the CoE members, the negotiations underline the difficult Franco-German relationship regarding terrorism. Both countries had very different experiences and policies on international terrorism and it was hardly possible to reconcile them. Franco-German

\footnotetext{
Anderson, "Counterterrorism as an Objective of European Police Cooperation," in European Democracies against Terrorism. Governmental Policies and Intergovernmental Cooperation, ed. Fernando Reinares(Aldershot etc: Ashgate), 227-244: 233, 237-238; Vercher, Terrorism in Europe. An International Comparative Legal Analysis, 351-352; Argomaniz, The EU and Counter-Terrorism. Politics, Polity and Policies after $9 / 11,5$.

${ }^{87}$ As scholars such as Malcolm Anderson point out Art. 7 has been ignored occasionally by governments that did not try suspects. The failure of states to abide by their legal obligations under international law, however, cannot be blamed on the Convention. For Anderson's argument see Anderson, "Counterterrorism as an Objective of European Police Cooperation," 238.

${ }^{88}$ Lagodny, "The European Convention on the Suppression of Terrorism. A Substantial Step to Combat Terrorism," 587.

${ }^{89}$ One should also bear in mind that the Convention had potential effects on terrorists too as it made it more difficult for them, at least so it must have appeared at the time, to escape justice. For a terrorist of David Rapoport's "Third Wave" this is an important psychological variable to take into account. Other than religious terrorists, social-revolutionary terrorists did not necessarily want to die when committing their attacks and the awareness that there were less and less safe heavens to which they could retire afterwards might have had discouraging effects.

${ }^{90}$ For the British interest in the matter see for instance Memo "Belgrade CSCE Follow-up Meeting. Brief No 28. Terrorism", no date (probably 7 or 8 November 1977), FCO 58/ 1132, UKNA
} 
cooperation - as much as it existed in other fields - did not extent to multilateral antiterrorism efforts.

Lastly, this article highlighted the leadership that Bonn showed when it came to the fight against terrorism. West Germany, being hard hit by terrorism, was prepared to initiate and see through complicated negotiations about a highly sensitive matter, one that had been historically enshrined in European relations: the rejection to extradite political criminals. While countries such as Italy and the UK had an interest in the Convention as well, it was Bonn that showed continuous commitment to the negotiations and the German government was the driving force behind the compromise that finally allowed France to withdraw its veto. Given the complexity of the issue, the adoption and ratification of the Convention was indeed a shining success for Bonn's anti-terrorism diplomacy. It had managed to have a presentable, albeit not ideal, convention on a sensitive issue adopted. West Germany had become a leader in the fight against terrorism. 